\title{
Quranic Verses and Sources of Ocean Energy
}

\author{
Mifedwil Jandra $a^{*}$, Shofyullah $M Z^{b}$ \\ ${ }^{a}$ Centers of Research and Community Engagement (LPPM), Sunan Kalijaga State Islamic University, Yogyakarta \\ ${ }^{b}$ Faculty of Usuludin And Islamic Thought, Sunan Kalijaga State Islamic University, Yogyakarta \\ *Corresponding author:jandraj6@gmail.com
}

\section{Article history}

Received: 2018-04-02 Received in revised form: 2018-08-13 Accepted: 2018-09-23 Published online: 2018-10-30

\begin{abstract}
This study related to Quranic verses about ocean and energy sources. The Quranic verses about ocean examined in two ways: classically and contemporarily. This study uses modern scientific commentary (tafseer) through the parallelistic approach. The aims of this study is to obtain information about the relevance between Quranic verses, natural phenomenon, energy sources, and the advantages. The commentary about ocean in the Quran offers some alternatives to several issuess. There is a lot of inventions in energy sources that found based on Quranic verses. Analysis on the verses about ocean shows that there is a match between the written verses (Qawliyah) in al-Quran and the natural phenomenon (Kawniyah verses). This is the greatest challenge to the modern civilization. Solutions in food safety and energy; health and medicine; transportation and good mobilization; environmental management, and the emerging of new dicipline in Islamic Marine Knowledge obtained after knowing the oceanic energy source. The hint found in oceanic verses helps to find solutions in technology for the human problem nowaday, at the future, and at the end human will use Ilahi guidance in their life.
\end{abstract}

Keywords: Oceanic Verses, Bahr, Islamic Marine Knowledge. 


\subsection{INTRODUCTION}

The Kawniyah verses also known as this empirical universe that we can observe, touch, measure and live in it, while they can also be addressed to verses literally inscribed in the al-Quran but specifically mentions or reveals about the empirical universe, which are not discussing about the Islamic or syar'i legal aspect of halal and haram, and all of the Islamic law syar'iyyah. Therefore, within the discourse of aqidah or the fundamental of faith, there are verses of Kawniyah, that means: 'the signs given by Allah in the universe', as the 'sign' of the existence of Allah, the sign of the Most Merciful, the sign of the Most Exalted, and all of the sign of Allah's existence. In the al-Quran there are verses that called as Kawniyah verses as called by Islamic Scholars. Al-Quran al-Karim, consist of 6236 verses, reveals all aspects of human's life, as well as inspire solutions based on al-Quran. Those explanations also known by scholars as the Kawniyyah verses. Quraish Shihab quoting Thanthawi Jauhari, in his desert venture (Al-Jawahir fi Tafsir Al-Qur'an, Kairo, 1350 H, jilid I, h. 3), He mentioned that there are more than 750 verses that obviously elaborates about the planetary processes followed by exposure of the universe with its phenomena. This figure does not include verses that explained it in between the lines or with symbolic terminology (Shihab, 2008). There are 42 "ocean" words in the al-Quran, with various topics and subtopics in regarding the ocean. This is not merely mentioned 'the ocean' in the historical context nor symbolic. The 'oceanic verses' not only reveals on how the prophet Musa AS split the ocean, or on the prophet Musa AS open the sea to let him and his exodus followers passed and escaped from Pharaoh, but also reveals about how we can discover fire or energy from the ocean deep. Or about the ocean that may sprout its water due to the impact exposed by the planetary phenomenon, what's happening on the orbiting sun and the opening of the sky. (Djamil, 2004). The anomalously high frequency of appearance of the oceanic words in the alQuran is impressive as all revelation of those oceanic verses were in Makkah and Madinah in the middle of the desert far away from the ocean. Secondly, the frequency of the 'oceanic' words outnumbers the frequency of appearance of 'religious' wording and terminology such as the word zakat, tahajud, thoyyiban, mutaharah, etc The frequently spoken words were recorded and searched using the following index in scripted in the al-Quran. The methiod of finding those words in the verses are using words-index and mathematical formulas. (AliAudah (1991), Badawi (2012) dan Corpus Quran (2012).

The earth is $72 \%$ covered by ocean, and only $28 \%$ land mass. Indeed, most of that water is very deep, average water depth is around 3800 meter, while the average land altitude is only around 400 meter. May be, this planet is rather called "Ocean" rather than "Earth", as if we may level up all the land mass all over the world, the planet will be a water ball with water thickness around 3400 meter thick. (Djamil, 2004). Even if we comparing it to the tallest volcano on earth, Mauna Kea Volcano which measured 10,200 m from its foot of slope, still less than the deepest of the ocean Mariana Trench, is 10,860 meters. (Engel, L., 1979, Talbot, F.H. \& R.E. Stevenson, 1991)

There are 42 occurrences of word "ocean / sea" in the Quran. This high frequency occurrence is relatively impressive firstly, in a sense that the Quran was revealed far from ocean, secondly, outnumbers other words that presumably very common (such as zakat, tahajud, thoyyiban, mutaharah, etc.). Word counts were based on Ali Audah (1991), Badawi (2012) and Corpus Quran (2012). 


\subsection{WHAT IS THE OCEANIC VERSES}

At Oceanic Verses, coined by authors, are selected verses in the Quran that contain word of 'Ocean' and 'sea' in several terminology like bahr, bahri, bahru, bihar, bahrayn, bahran, bahrayni. 'Sea' or' ocean' also were meant in several other verses but neither mentioned in such those words, but instead by word Yammi(u), suffix "hi”, and suffix "na/in". Attentions were given on the Semantics, Ontology and Categorization aspects of oceanic verses as revealed and found in 42 verses in Al Quran. Word 'bahr' and its variation in those verses were studied semantically first. Key words surrounding the 'bahr' words were analyzed and cross-checked with relevant verses to grasp the closest message and guidance. Later, ontologically study the nature of existence of the oceanic verses, their realm in the knowledge system, and Categorization of being and their relations.

\subsection{Kawniyah Verses (Natural Phenomenon)}

Kawniyah verses known as this universe or Quranic verses about the universe, not about syar'iyyah law. The word Kawniyah comes from the word , k-w-n. Kawn means 'phenomenon' and then translated to universe that means phenomenon that known and created by Allah. Therefore, kawniyah means 'something made' and every things that made by Allah is this universe, from micro-cosmos until macro-cosmos.

Kawniyah verses also means the writing (verses) in al-Quran that contains about the universe. Some scholars said that Kawniyah verses is a verses that discuss the creation of the universe. AlQuran al-Karim consists 6236 verses that explains about life or related to the universe and its phenomenon. The Kawniyah verses also mentioned as a verses in al-Quran that the contain is about the universe. Some scholars called Kawniyah verses is a verses that discuss the creation of the universe. The description about those things called Kawniyah verses (Shihab, 2008: 113).

Kawniyah verses or natural phenomenon fundamentally can be seen directly i.e. through:

a) The shape and position of the moon that changing according to its orbit.

b) A thin light that cover some parts of the earth in the noon.

c) Planets that move orderly and periodically on their own orbit.

d) Water that falls from the sky.

e) Water that flows to the lower place, either in valler or in the deep sea basin.

f) The waves on the ocean that move and flow.

g) The green plant that can be burn or green plant that can bear the sun light through the day.

h) The everlasting darkness in deep ocean, either in daylight or nighttime.

i) The bitter and salty ocean water that meet the fresh water.

What is mentioned in al-Quran surat an-Nur verses 40 about the darkness in the deep ocean as if repeat the evidence that has been proved by science nowaday. Narrated the book "Oceans" by Danny Elder and John Pernetta, the darkness of sea and the ocean can be seen in the depth of 200 meters or more. In this depth, the light almost cannot pass through. In the depth of 1000 meter, the light cannot pass through at all. 
Human can take the wisdom from the Qauliyah verses in al-Quran and Kauniyah verses in the universe, especially about the sea. The sea can be used as a media to get know Him. The real phenomenon that have been proved by human shows that there are no doubts in Allah Azza Wa Jalla's word. Truth what He says, Allah the most magnificent.

About the sea water that never mix, Allah says:

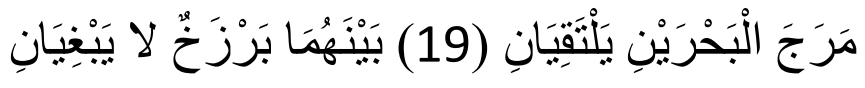

"He released the two seas, meeting (side by side). Between them is a barrier (so) neither of them transgresses"[Q.S. Ar-Rahman ayat 19-20]

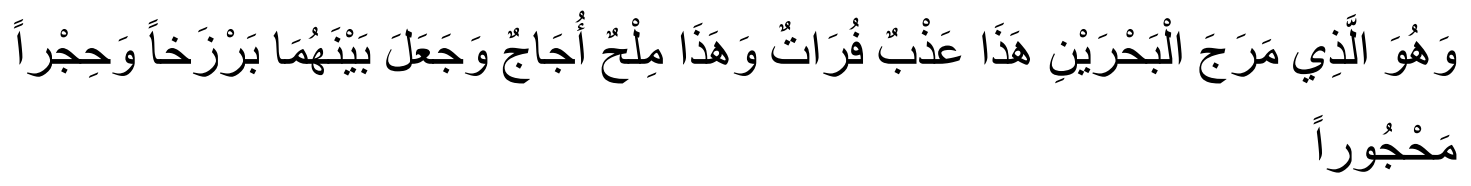

"And it is He who has released (simultaneously) the two seas, one fresh and sweet and one salty and bitter, and He placed between them a barrier and prohibiting partition" [(Q.S. AlFurqaan ayat 53]

\subsection{Sustainable Energy}

The term energy source in this study taken from the explanation of energy that available sustainably and unlimited. Energy from the ocean is a eternal. In this post-modern era, energy source is a problem that always been searched. The interesting point is that the clue about energy source can be known from the holy Quran.

The advantage of energy from the ocean is the broad abundance because the ocean cover $72 \%$ of the earth. In oil and gas sector, most oils and gases can be found in the sediment basin (Djamil, 2004).

Energy is one of the primary needs of human life; to warm their body, to make their food, to run the transportation and move both things and theirselves from a far place easily and optimally; as the light source in the night. In short, energy can make people happier and build a higher civilization (Pedwirny, 2010:122).

If we carefully sort back the energy chain about the energy source on the earth, it will be clear how chlorophyl plays a fundamental role in the beginning of the change of energy from electromagnetic radiation, specifically the red spectrum $(\alpha=650-680 \mathrm{~nm})$ and the blue spectrum $(\alpha=430-500 \mathrm{~nm}$ ), leave the green and other spectrums to be reflected and soothe our sight. Chlorophyl had done their job since a hundred year ago in changing the energy from the sun to generate fossil fuel or hydrocarbon compound i.e.: oils, gasses, charcoal, methane, and peat. The brown stems are rich of selulose and can be directly used as biomass for firewood and charcoal. Peat that comes from the stems will be decomposed and turn to methane gases. While the wood will become fossil after million years, then turn to charcoal and methane gases.

Other compounds that least studied is the effect of magnetic solar in suppling energy to the earth. Along with the advancement in science and technology, hopefully this phenomenon can be more understood and utilized. 
Green leaves or green cells from plant can be eaten directly either by animal or human. It can also be eaten by animal and then the animal consumed by human. Both herbivore or carnivore, when its die, their flesh will be decomposed and buried for million years and become fossil. Fossils are rich of carbon (C) and will be transformed to hydrocarbon or oil and gas after buried under the surface for million years. Then, oils and gasses will be used to generate electricity to turn on the car machine. $\mathrm{CO} 2$ as the residue will be recycled with water $(\mathrm{H} 2 \mathrm{O})$ by green plants, either in the land or ocean to produce oxygen (O2).

Energy can be obtained from the ocean, either in the form of convetional energy we used to know or non conventional energy that we don't know yet. Mentioned in al_Quran that we may seek of His bounty in the ocean and perhaps you will be grateful. (an-Nahl: 14).

\subsection{Energy that Constantly Available}

Energy that stir the water (hydrokinetic) is called perpetual energy. This energy is stronger and last longer than the renewable energy.

\subsubsection{Energy from Water Flow (Hydrokinetic)}

Hydrokinetic generator is a electricity installation from the move of water flow.

(1) Stream

Sea stream and river stream flows perpetually or eternally just like the tidal stream. This global movement affected by the earth movement towards the axis. Surah Yasin verses 39-40 explains about the earth rotation towards its axis so the regular moon phases can be seen.

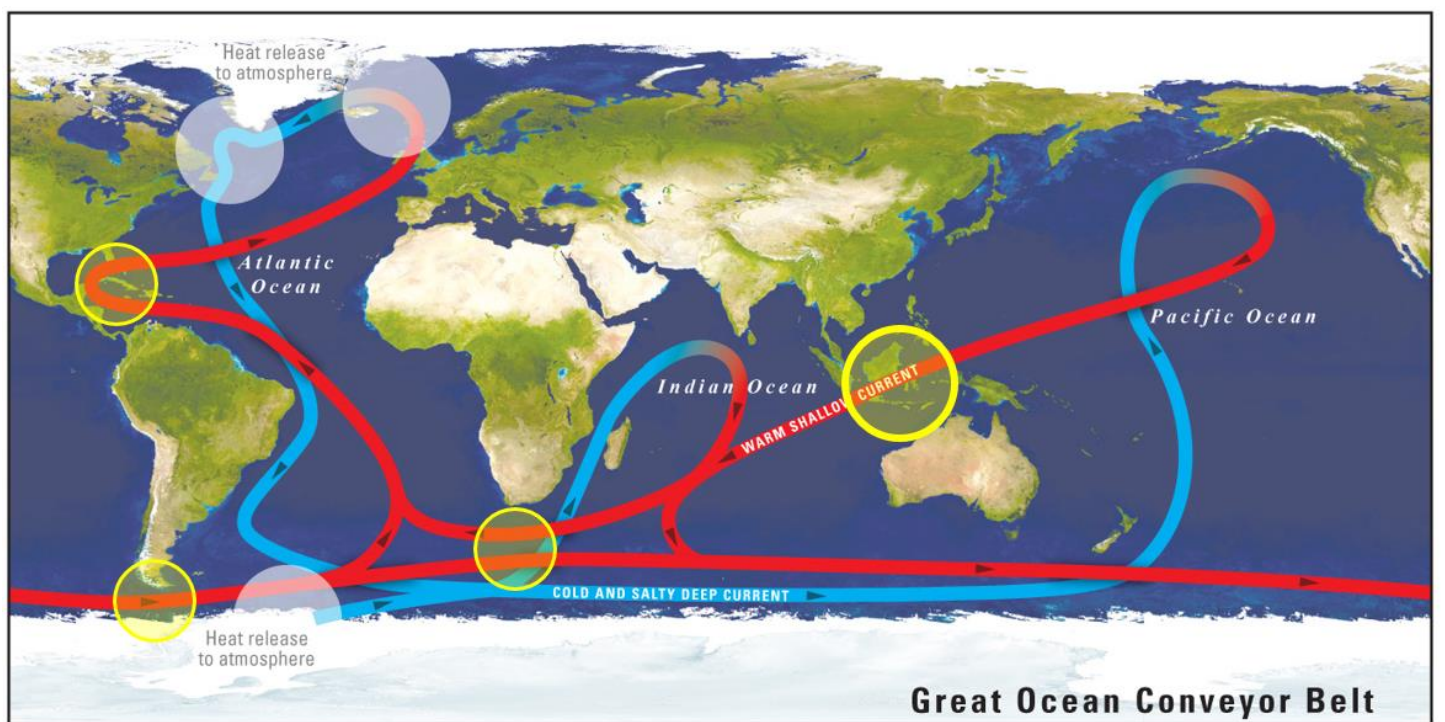

Image 1 The earth rotation towards its axis so the regular moon phases (Source: Great Ocean Conveyor Belt - USGS Professional Paper 1386.)

The thermohaline stream of the Great Ocean Conveyor Belt that pass right in the center of Indonesia archipelago.

Ocean stream that moves globally, massively, and also eternal is known as Global Conveyor Belt (see Image 1) that when pass through Indonesia territorial water that located right between two biggest world ocean (Pacific and Indian Oceans), it carries $15.000 .000 \mathrm{~m} 2$ warm water stream Page | 25 
(thermohaline) every second. When this stream pass through some narrow straits in Indonesia territory water, this stream become an eternal energy source and can be used to power the electricty generator turbine.

(a) Stream that flows in the open ocean of a wide ocean. For example in the ocean stream of Humbolt in Atlantic Ocean, Kuroshio and Oyashiwo stream that flow through Pacific Ocean.

(b) Stream that flows in a strait between two islands. For example in Sula strait as the part of Arlindo stream that pass through the eastern Islands of Indonesia.

(c) Stream that flows in a semi-closed bay. For example in Teluk Saleh bay in the Island of Sumbawa in the center part of Indonesia. In the front of Teluk Saleh bay there is Mojo Island that become a close door for this wide bay. In both of the end of Moyo Island, there are two narrow gap (width 300-500 meter) as the location for water stream to passing by.

(d) Stream that flows in the straits between islands or islets as happens in the strait between Riau archipelago in Malaka strait that really affected by a quite big tidal stream.

(e) Around the terrestrial river, there is a swift stream in the upstream of river or rice field irrigation.

This hydrokinetic energy is more eternal than wind energy, conversion of ocean thermal energy, and solar energy. The wind energy is depending on earth temperature change, while temperature in the earth surface depending on solar thermal that happens less than 12 hours a day. Solar energy depending on the solar radiation. The OTEC (Ocean Thermal Energy Conversion) technology have a lower effectiveness because the solar thermal is only less than 12 hours a day, whereas the variation of temperature in the surface of ocean depends on solar radiation and the depth of ocean.

\section{(2) Tidal Stream}

This stream is affected by the tidal wave. This tidal stream move periodically every 6 hours a day. The magnitude of this stream depends on the sea surface size area that affected by moon and solar gravity.

The dynamic up and down movement of water surface near the shore, bay, strait, and estuary area is almost perpetual and moves 24 hours a day. Usually, the effect of this tidal stream is near to the city or residential area. Therefore it also close to market or high demanding area and sustainable.

This tidal stream energy if a direct effect from the solar system constellation that move regularly in their orbit. This is the best phenomenon for human to use the energy source from a tremendous gravity area, so that moon moves in its own orbit, therefore the sun that run in its galaxy constellation rapidly, and earth that consistently rotating in its axis since billion years ago (Kosnic, 2008: 72).

The force gravity field that hold the earth, the moon, the sun, and other planets in solar system is extremely precision and eternal. It's not a coincidence if Allah explains about the movement of sun, moon, earth, and the change of day and night in surah Yasin(36) verses 37-40. And then He introduce Himself by showing verses or the sign of His power and His wisdom in surah yasin verses 36 as the 'Aziz il 'alim' that means The Mighty and The Knowing. And water in the surface of the eart is the only substance to bring out the energy from this gravity field.

Page $\mid 26$ 
Until now, gravity is still become an enigma in the discipline of physic. Surah Yasin (36) verses 37-40 about the water movements as explained in surah ar-Ra'du(13) verses 17 may become an important answer and a solution to energy resilience threat for the human being. The tidal stream that moves eternally can be used to generate the electricity generator turbine.

(3) Waves

Ocean waves able to erode rock in the shore or destruct rocks until become sand, swaying a ship on the ocean, that shows a great energy that almost eternal.

Waves on the all along the coastal beach meet the open ocean directly like in the southern coastal beach of Java island, the western of Sumatera island, and the southern of Bali and Nusa Tenggara Island. Not every coast experienced the waves crashing, but in the shore side that face the high seas directly experienced a strong waves crashing all the time (see image 2). This periodic moves of waves can be used as the source of energy to generate electricity (Bahaj, 2011: 101).

\section{HYDROKINETIC ENERGY OF WAVES THAT ERODE THE HILLS}

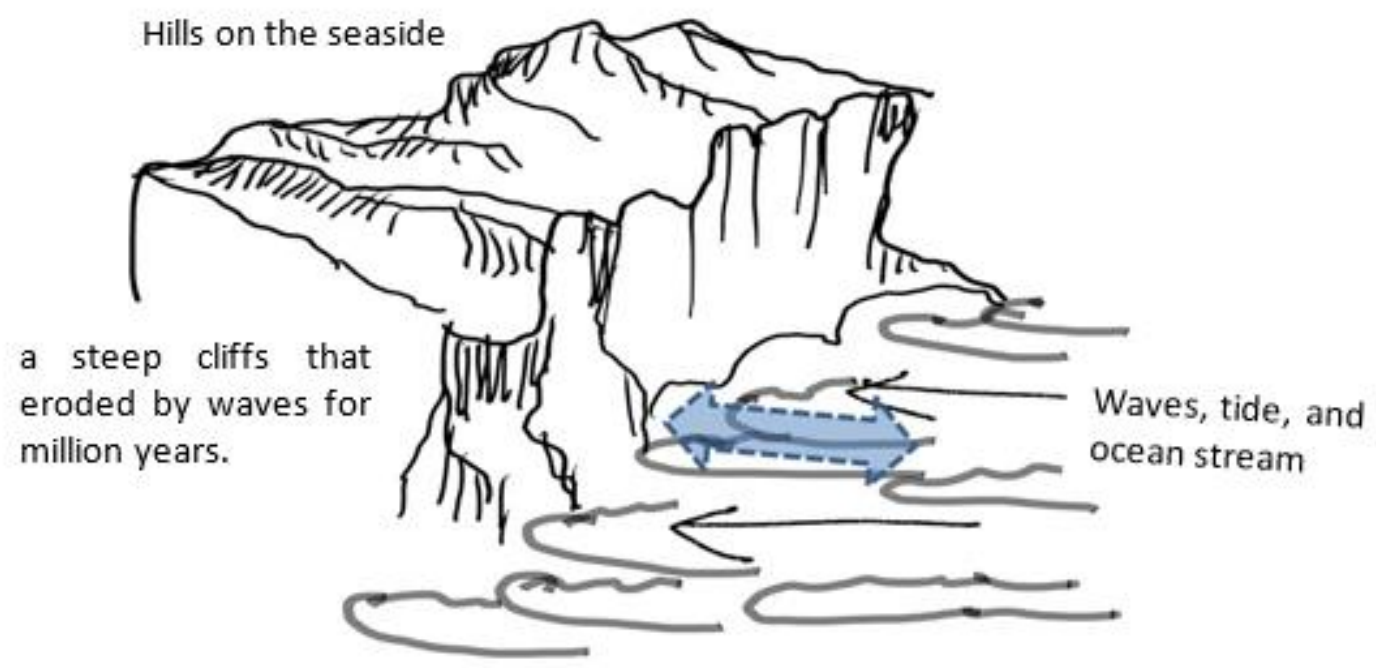

Image 2: Waterwaves that erode the cliff remains a steep cliff.

Waves movement can be seen clearly so the technology on this energy source is relatively more advanced than other technology.

The problem to generate greater electricity energy is the equipments should be in a great capacity. When an advance technology placed all along the shore or floated in on the sea, it can interfere ships traffic.

\subsubsection{Mariculture Energy}

Mariculture Energy is an economic activity that run an agriculture activity on the sea that aimed to obtain biomass to get the source of energy.

Page | 27 
The author presume that there are other greater energy sources from the ocean in the form of algae that rich of lipids to produce biofuel, algae and othe sea plants that rich of cellulose to produce bioethanol, algae, seaweed, and seagrass to produce biomass.

Tropic state with warm and great ocean water like Indonesia, Malaysia, and Philipine is an interesting location to arose the mariculture technology on algae as to produce biofuel and bioethanol.

Surah Yasin(36) verses 80 and al-Waqi'ah (52) verses 71-74 mentioned that green plants can be used as fuel or energy source and it brings us to appreciate the important role of chlorophyl that exchange the heat energy of sun to other form of energy that can be used by human. And it guides us to find other prospect in energy that based on the ocean.

Because of the sun light up the ocean as $72 \%$ of the earth surface, so the solar energy in the form of electromagnetic wave can be captured and exchanged to chemical energy in the ocean more than in the land.

Ocean plants like algae, some phytoplankton, and seagrass have a lot of advantages as energy source for the reasons as follows:

(1) Highly contain chlorophyl, 10.000 times more than land plants.

(2) Algae growth rate is faster than the trees in the tropical forest.

(3) The space for algae to grow is 3 times wider than soace on the land.

(4) The space for sea plants to grow is not used by human and the oil levels is better than palm oil or biofuel from cassava.

Ocean cultivation allows us to grow and reap the sustainable energy and plants with chlorophyl and cellulose that grow rapidly in the ocean, i.e:

Algae, a single cell lower plant that rich of chlorophyl.

Algae or single cell lower plant or single cell sea creature also known as zooplankton. Green and brown algae contain high fat or oil. This oil can be extracted and processed into biofuel or biodiesel.

Seaweed

Seaweed contains cellulose that can be processed into ethanol. Ethanol is a kind of alcohol that can be a clean fuel.

Kelp and Seagrass

Plant in shallow sea that contains cellulose and can be cultivated to produce bioethanol.

\subsubsection{Wind}

Wind in the ocean and coast have a great velocity and power that can reach 10 kilometer/hour. Nowaday, wind energy in the offshore considered as a promising energy source and already built commercially in several countries, i.e: America, Germany, China, Denmark, and any other developed country.

Today, generator that produce electricity using wind has been built, either in the land or the ocean. The biggest turbine in the land is the SeaTitan 10MW Wind Turbine that built by the 
AMSC company from United State of America. This giant structure reach 125 meter height and the rotor reach the diameter 190 meter. The next biggest wind turbine is the Sway Turbine ST10 with capacity 10MW in Norway; the Areva 8MW Turbine in German, the Vestas V164 8.0 MW Turbine in Denmark; the Enercon E-126 7.5 MW Turbine in German, the Samsung S7.0-171 7 MW Turbine in Scotland, the Repower 6.2M152/Repower 6.2M126 6.2 MW Turbine in Germany, Netherland, and Belgium; the Siemens SWT-6.0-154 6 MW Turbine in Denmark, the Haliade 150 6MW Turbine in France, and the Sinovel SL6000 6 MW Turbine in China (Kosnik, 2008: 93).

The problem is wind energy is not consistent and unpredictable. Other problem is the need of iron in a big amount to build a large turbine for larger electicity necessity.

\subsection{Electricity Altenatives}

Sine 1900 until 2008, the world population that got an acces to electricity is just 2 billions people. According to International Energy Agency (IEA) there are more than 1.3 billions of people that still not receive an adequate electricity access. And according to United Nations (UN), there are 1 billion other that experincing the same problem (http://www.hijauku.com).

Indonesia have a low electrification level, just $60 \%$ of total population that have an appropriate access to electricity. The national power installation in 2010 is about $25 \mathrm{GW}$ that equivalent to Netherland (16 millions population) and Sweden (8 millions population). To fulfill 100\% electrification, Indonesia should upgrade the power twice from the installed power today. This massive job needs a massive energy source and also a massive transmission and distribution. The massive distribution system can be helped by can be helped by electricity generation spread evenly across many islands, so that interconnection system is not the backbone, but a back up distribution system. The rest of population (40\% Indonesia population= about 100 million peoples) that need electricity is particularly located in:

1) The rural areas that far from the installed electricity distribution grid. This problem is also a challenge to electricity provider to provide an affordable price for the lowest stratum society in social pyramid.

2) The archipleago area along Indonesia that spread out largely. The range is equal to the distance from London to Istanbul.

It has to be considered that Indonesia and ASEAN region is one of the region that have the fastest and greatest economic growth in the world. The elasticity energy (Elasticity energy: ratio percent energy increase / percent GDP growth) increasing correlated to rapid economic growth in emerging market countries in East Asia. To fulfill the energy usage per GDP per capita, the energy intensity (energy intensity: TOE / US\$ GDP per capita) per capita should be increasing, whereas the population also increasing rapidly. The total energy required is multiplying (Agus Djamil, 2014:123).

\subsection{The Benefit from the Sea and the Suitability to Quranic Verses}

Confirmed in the Quran that water is a source of life "and We made from water every living thing? Then will they not believe?" (surah al-Anbiya' verses 30) is not just related to biological elements which the activity of eating is just put in an energy from the outside to the body and doing activity is how to take the energy out. Water is also a source of life. Physically, water is a 
perfect medium to capture-save-pass on the energy. In this case, energy from the interaction of earth-moon-sun gravity stored in the ocean water that moves up and down all the time.

As mentioned above, ocean have a great potention so that have a lot of benefit to human life. We can get various of sea animals to be eaten or sold to get money to fulfill the daily needs. For example the fish, seaweed, clams, pearls, and many other. This is match to the Quran:

"He who subjected the sea for you to eat from it tender meat and to extract from it ornaments which you wear. And you see the ships plowing through it, and [He subjected it] that you may seek of His bounty; and perhaps you will be grateful." (Surah An-Nahl verses 14).

The sea is also functioned as transportation track that allows us to go from one place to another place. The transportation we use is various types of ship.

"It is your Lord who drives the ship for you through the sea that you may seek of His bounty. Indeed, He is ever, to you, Merciful.” (Surah Al Isra [17] verses 66).

"And of His signs is that He sends the winds as bringers of good tidings and to let you taste His mercy and so the ships may sail at His command and so you may seek of His bounty, and perhaps you will be grateful.” (Surah Ar Ruum [30] verses 46).

Allah has given grace to humans in the form of intelligence that leads the human to think until theyr are able to build a ship that stays afloat on water and can sail from one place to another. All of this happened in His permission. Therefore, as a humans that are given grace, gifts, and trust by Allah should not ruin those.

He gave humans many gifts in the sea that have a great benefit to human, animal, and plant. Human can use the food source such as fish, seaweed, and the ocean water can be processed to salt. We cannot live without water. There are many life inside the ocean, such as fish's life, coral reef, seaweed, clam, crocodile, and any other form of life. So are in the lake and river.

There are a lot of resource in the ocean, such as salts, plants, coral reefs, fishes, phosphate, waves, tidal stream, pearls, planktons, and offshore oils. Below are the explanation of those resources:

1.Salt: is one of the seasoning that must be used in cooking. Salt contains iodine that potentially prevent cancer and reduce acne. Salt comes from ocean water that evaporatd and remaining salt granules. It can be processed traditionally using solar energy or fire and can be in modern way using machinery.

2.Fish. Fish in one of protein source for human. Fish is a renewable resource because they are able to reproduce. But, as the impact of illegal hunting that ignore the ecosystem aspect, a lot of sea creature become endangered. One of it is the flying fish which its egg considered as a luxurious food called caviar.

3.Plant: The sea also have a living plant that functioned as a place for fish to live. Not only for fish, the sea plants also have a lot of benefit to human. Sea plants such as seaweed contain high fiber and good for digestive system. Seaweed also used as the main material to make drug capsules.

4.Coral reef: is one of sea plants. Coral reef can live in the shallow sea. Some coral reefs considered as an indicator to sea water cleanness. Moreover, coral reef can produce oxygen that 
comes from photosynthesis process. There are various types of coral reef. Each of it can be a place for fish to live. Coral reefs beautify the ocean and become a tourism spot.

5.Phosphate: is a bones of dead fish. Bones of dead fish that contains phosphate are collected and crushed and used as organic fertilizer.

6.Tide: is the change of sea surface height because of the moon gravity. The tide is used by fishermen to work. They go to the sea at the tide and go home when the tide low. Not only that, tide is also used to turn on the lighthouse on the cliff. The lighthouse is used as a sign of cliff around the lighthouse and help the ships to determine direction.

7.Pearl: is one of the resource from the sea that have a high economic value. Pearls comes from clam. When the clam is given a solid food, it will wrap the food with its saliva thus pearl produced. Human utilize pearl as jewelry. Moreover, the pearl extract can be used to whiten the skin. Pearl is one of sea resources that can be renewed because human can culture the clam.

8.Plankton: is a tiny sea plant. It is usually use as an ingredient for pet fish food. Because of its size, plankton cannot be seen clearly by naked eye.

9. Offshore oil: is a crude oil inside the ocean. In Indonesia, offshore oil can be found in Java sea, South China sea, Celebes sea, and Malacca sea (Pedwirny, 2010: 98).

Water covers most of the earth, like the ocean, lake, river, and well. It's very useful for plant. Plant cannot grow without water because soil needs water to prevent aridity. Water also fertilize the soil and refresh the plants (Harun Yahya, 2003:99).

Plants without water won't be fresh, human and animal without water cannot live, that is why water is an important life source for living creature. Allah created everything with purpose, none of them are useless. Allah is The Greatest that has created this universe perfectly. So that we must utilize the water in this earth wisely. least

\subsection{CONCLUSION}

Qawliyah verses and several studies on ocean energy (an-Nahl, 14, At-Tur, 6, ar-Ra'du, 17, anNur 40, and Yasin, 80) and (Yasin, 36-40, ar-Rahmaan 19 - 22, at-Takwir,1 - 6, and al-Infithar, 1 - 3) are parallel to the Qauliyah verses in this universe that related to energy source from the ocean. It shows that the most interesting field to be studied, examined, and revealed deeper is the hydrokinetic energy or other energy related to water movement, particularly the movement of ocean stream, either in the offshore, strait, or tide from the front of bay, islands, and estuary.

Variouse alternative resources that can be obtained from the ocean showed us that the adequacy of energy is one of Allah's promises. But, those reources must be used effectively so that can be used as a prospective, reliable, and affordable energy source.

Hydokinetic energy have the most interesting prospect, either in principle aspect, concept, or the study advancement until this day. Ocean stream that experience the tidal movement all the time allow for hydrokinetic technology development.

\section{Acknowledgement}

This Study Is The Result of Research Funded By LPPM UIN Sunan Kalijaga Yogyakarta References

Page | 31 


\section{Reference}

Agus S Djamil. (2004). Alqur'an Dan Lautan. Ar-Rasy Mizan: Bandung.

Ali Audah. (1992). Konkordansi AlQur'an. LiteraAntar Nusa: Jakarta.

Al-Jalalayn. (2012). Tafsir al-Jalalayn. Royal Aal al-Bayt Institute for Islamic Thought: Amman, Jordan.

Departemen Agama R.I. (1979). Al Qur'an dan Terjemahannya. Departemen Agama. Republik Indonesia.

Elsaid M. Badawi and Muhammad Abdel Haleem. (2008). Arabic-English Dictionary of Qur'anic Usage, in Handbook of Oriental Studies Handbuch Der Orientalistik Section One, The Near And Middle East, Volume Eighty-Five by H. Altenmüller, et al (Ed). Koninklijke Brill NV: Leiden, The Netherlands.

F.H. Talbot \& R.E. Stevenson. (1991). The Encyclopedia of the Earth: Oceans and Islands.

Ibn 'Abbas, translation by MokraneGuezzou. (2012). Tafsir Ibn 'Abbas, Royal Aal al-Bayt Institute for Islamic Thought: Amman, Jordan.

K.C. Condie. (1982). Plate Tectonics \& Crustal Evolution. Pergamon Press: New York.

Kais Dukes. (2009-2011). The Quranic Arabic Corpus. Diakses pada 03 April, 2016 daripada http://corpus.quran.com/

L. Engel. (1979). Laut, Pustaka Time-Life.

Marek Obitko (advisor Vladimir Marik). (2007). Translations between Ontologies in Multi-Agent Systems. (Ph.D. dissertation). Faculty of Electrical Engineering. Czech Technical University. Prague.

P.J. Wyllie. (1971). The Dynamic Earth: Textbook in Geosciences. New York.

Runes D. Dagobert. (1976). Dictionary of Philosophy. Adam and Company: New Jersey.

Sahih International. (1997). The Quran: Arabic Text with Corresponding English Meanings. Almunatada Alislami. Abul Qasim Publishing House.

T. R. Gruber. (1995). Toward Principles for The Design of Ontologies Used for Knowledge Sharing. International Journal of Human-Computer Studies, 43(4-5), 907-928 access from http:/ /wwwksl.stanford.edu/kst/what-is-an-ontology.html

Wikipedia. Diakses pada Desember, 2012. daripada http://en.wikipedia.org/wiki/Ontology.

Yahaya Yusoh and Azhar Muhammad. (2012). Falsafah Ilmu dalam Al Quran; Ontology, Epistemology dan Aksiologi. UTM Press: Johor Bahru. 